\title{
Multimedia Assisted Analogy: Learning Approach to Developing Mathematical Representation Skills
}

\author{
Gelar Dwirahayu ${ }^{1^{*}}$, Dyah Tantri ${ }^{2}$, Afidah $^{3}$ \\ 1,2,3 Department of Mathematics Education, UIN Syarif Hidayatullah Jakarta, Indonesia \\ e-mail: gelar.dwirahayu@uinjkt.ac.id¹, dyahtantrikusumaningtyas@gmail.com², \\ afidah@uinjkt.ac.id $^{3}$
}

\begin{abstract}
This study aims to examine the application of mathematics learning using a multimedia-assisted analogy approach in developing mathematical representation. The sample used was grade 7 students of two classes, totaling 44 students. The research method used was a quasi-experimental design with randomized posttest only. Two classes were randomly selected as samples, namely class VII-1 as the experimental class and class VII-3 as the control class. The analysis was performed using the $t$-test at $\alpha=5 \%$, obtained $t$-count $=4.205>t$-table $=2.018$. The results indicate that the mathematical representation ability of students whose learning uses the analogy approach is significantly higher than students whose learning uses a conventional approach or in other words, the multimedia-assisted analogy approach can be used as alternative learning in developing student representation abilities especially in algebraic material.
\end{abstract}

Keywords: Analogy, Mathematical Representation Skills

\section{Introduction}

According to the National Council of Mathematics Teachers, representation skills is one of the five aspects of ability that must be developed in teaching and learning mathematics. The other four skills are reasoning skills, communication skills, connection skills, and problem solving skills (Reys, 2010, Hutagaol, 2013; Dwirahayu, 2018). The process of representation in translating problems or ideas into new forms (NCTM, 2000). Proses representasi melibatkan penerjemahan masalah atau ide ke dalam bentuk baru (NCTM, 2000). Representation in general is a model a problem situation as a result of the interpretation of thought. This representation is the delivery of mathematical ideas in a more tangible form so that other people understand them (Setiadi, 2012). Representation has an important role in learning mathematics, representation can be seen as an internal abstraction of mathematical ideas or cognitive structures built by students through experience; as a new mental formation from a previous mental state; as a presentation of students' cognitive structures through pictures, symbols or symbols (Herdiman, 2018; Sabirin, 2014). The ability of mathematical representation needs to be developed because it will help students make more concrete ideas so that students understand concepts more easily and solve complex math problems becomes simpler (Sari, 2018). It is also overcoming the stigma of mathematics as a boring, uninteresting and difficult subject to apply, because mathematics is always associated with abstract formulas and problems.

The ability of representation does not mean the final product of mathematical solving, but representation is more emphasized on the construction of new and different knowledge than before, for example in understanding mathematical concepts, operations, and its relationships (Sabirin, 2014; Sulastri, 2017). The representations presented by students are mathematical ideas in an effort to find solutions to problems that are being developed ( Sabirin, 2014; Sulastri, 2017) . Representation can be presented in three ways, namely through action, through visual images or through words (Herdiman, 2018; Kartini, 2009; Minarni, 2016) or a combination of the three (Hutagaol, 2013).

Based on information obtained from the results of research by Misel and Herdiman shows that the ability of students in several schools in Indonesia has not been able to present mathematical concepts or ideas properly (Herdiman, 2018; Misel, 2016). Furthermore, student

\footnotetext{
${ }^{*}$ Corresponding author.

Received 13 April 2020; Accepted 01 October 2020; Available online 25 March 2021 (C) 2020 JPI. All Rights Reserved
} 
mathematics learning outcomes in Indonesia are still low, this is related to the low ability of mathematical representation (Annajmi, 2016; Sulastri, 2017). Efforts that can be made to optimize students' mathematical representation abilities are by selecting the right learning model. Developing the simplest student representation abilities is to get students closer to the environment. Teaching mathematics through real contexts will train students to connect real contexts with mathematical concepts (Annajmi, 2016). The analogy learning approach is an approach that helps students understand new concepts easily because it is through other simpler concepts and illustrates real life examples.

Analogy is a mathematical ability that can describe an abstract concept into concrete or real objects, this is done to make it easier for students to understand mathematics. Analogy is also defined as the process of drawing conclusions from two different things (Dwirahayu, 2018) to determine their similarities. The analogy process will help students form new schemes based on previous schemes or previous knowledge which are expected to form a heterogeneous representation between one student and another so that representation skills can develop properly. Analogy can be used as a tool or approach in learning mathematics (Simms, 2017). Analogical reasoning is a thought process by representing ideas, information and objects in the real world as an interconnected system (Richland, 2016). The results of research show that analogy learning can improve the reasoning skills of high school students on derived material (Dwirahayu, Mubasyiroh, Afidah, 2018). Other research shows that learning with the analogy approach has strong reasoning power in teaching physics concepts because with analogies students are able to find inspiration, construct knowledge based on previous knowledge (Simms, 2017). Learning with an analogy approach helps students understand the concept of photosynthesis, the teacher teaches the concept of photosynthesis by analogizing it to the processes that occur in plants (Maria, 2011). The analogy approach is very effective in transferring knowledge so that students are able to construct knowledge from analogy to target concepts.

Learning using an analogy approach is focused on students' attention to build a connection between two events, two examples or two things (domains) (Gentner, 2012), not letting students focus on the events or problems that is arised (Richland, 2016). Therefore, the analogy learning process used in this study does not display an incident where students are asked to focus on the incident and then look for similarities between the two events, but in beginning the learning process carried out in this study uses an incident, then with the guidance of the teacher, students directed at finding similarities that exist in the incident presented with the concept to be taught. The analogy learning technique used in this study uses six steps adopted from research by (Glynn, 2007; Kristayulita, 2015; Lindsey, 2004). The first step is to introduce students to the concept of algebra by using lectures, the second step the researcher uses multimedia as a medium that introduces analogue concepts and to understand students' initial understanding of the application of algebraic concepts that they often find in everyday life. After that, students must report what they find in their ril life, the third step is students who observe to make a connection or connection between the events in the video with the algebraic forms being studied. In step five, using the Student Worksheet, students to identify of similiarity shapes. At this stage the researcher uses two forms of similarity, namely similarity of symbol and similarity of incidents. The similarity of symbol is used to explain the basic concepts of algebra, while similarity of incidents is used to explain the concept of algebraic operations. The fifth stage is to explain when analogy can be applied. Sometimes there are the same events that are not analogous to the concept of algebra. In this study, the researcher provides an example of water and oil events, this event can be used as an analogy to algebraic addition operations but does not support other operations. The last stage is a conclusion about the concept of algebra, the teacher and students together make conclusions from what has been done using the analogy approach.

The importance of analogical reasoning in learning, because it can improve students' ability on recognize and analyze the relationship between new knowledge and previous knowledge. besides that, analogical reasoning can abstract mathematical concepts are associated with real life students and analogical reasoning is able to provide a fairly long memory (Lailiyah, 2014). Analogy as a process of thinking about the transfer of information 
and meaning from a particular subject (analog or source) to an another specific subject (target), analogy is also a language representation that shows the process of implementing the relationship between the two subjects (analog and target) (Loc, 2014). Based on this, analogy learning is known as analogue concepts and target concepts (Lindsey, 2004; Basir, 2018). In principle, the application of analogy in learning, the teacher must produce an analogy concept for the target concept so that the initial concept / analogue concept is conveyed well to students. The advantages of the analogy approach in learning mathematics include: helping students understand new concepts easily because of other simpler concepts; Training students' reasoning skills because students are faced with two similar but different problems, students who monitor to find similarities and differences; understanding abstract concepts that refer to examples in real life; analogy requires the teacher to consider the initial knowledge / concepts that students have so that the learning process carried out will reduce students' lack of understanding of the material or concepts being taught (Dwirahayu, Mubasyiroh, Afidah, 2018). The forms of analogy that can be used in learning include using: diagrams, short sentences, actual physical experiences, simulations, activities using computers (Dwirahayu, 2018), concrete objects (Hafiz, 2016) or what is known as media manipulative.

Research conducted by Zuchri shows that manipulative media can bridges between real-world contexts and mathematical concepts (Zuchri, 2017). Manipulative media in learning mathematics can: introduce mathematical concepts more easily and varied, students can practice math facts and concepts, improve mathematical concepts, and improve students' ability to solve problems. Furthermore, Nizham in his research uses visual media to provide real illustrations of operations on integers (Nizham, 2016). The results of his research indicate that learning media in visual form can help develope students' understanding, especially in the concept of numbers. Thohirudin's research also utilizes two different media simultaneously, namely plastic mica media and Geogebra software (Thohirudin, 2016). The results of his research indicate that plastic mica media and Geogebra software help students understand the concept of building space very well, because by using these two media, students can easily visualize images.

The results of previous research shows that the analogy process is able to develop students' thought processes and the use of media help teachers in visualizing real objects. This study analyze of the process of learning mathematics in algebra material uses a multimedia-assisted analogy approach, with the hope that the combination of analogy and multimedia approaches in learning will be more effective. Teacher shoudl prepare their lesson plan with context presented real with the help of multimedia. The use of multimedia in analog learning makes it easier for teachers to find or determine analog concepts. This helps teachers realize the real form of objects that are teaching, making it easier for students to understand learning materials so that they achieve the target concept (Chiu, 2009). Therefore, multimedia is needed in an analogy strategy to support every stage of the learning process

The multimedia used in this study is a powerpoint slide that shows pictures and animations that are effective in supporting the delivery of subject matter. Multimedia also integrated with the learning videos. Multimedia is used as a manipulative of target concepts, namely mathematical concepts that created as a form of concrete representation of objects that are thought to be known by students, so that the manipulative material added is between the students' possibility of making image connections with the expected mathematical ideas. So that in the end the multimedia-assisted analogy approach will provide a better understanding to students and able to develop their representation skills.

Based on descriptions above, this study aims to focus on developing mathematics learning by using an analogy approach that is assisted by multimedia to develop students' mathematical representation skills.

\section{Method}

This research was conducted at the Ruhama Islamic Junior High School in the city of South Tangerang in the 2017-2018 academic year, from October to November. The research method used was a quasi-experimental with a posttest only control group design. The population in this study were 4 classes of grade VII students at SMP Islam Ruhama. The 
sample was randomly selected and class VII-1 was selected as an experimental group, namely a group of students learning mathematics using the multimedia-assisted analogy approach as many as 24 students and class VII-3 as a control class, namely a group of students who studied using the conventional approach as many as 20 students. The instrument used to measure the mathematical representations' skills is a test in the form of a description of 8 questions which is described in three indicators, namely visual representation (2 questions), verbal representation (3 questions) and symbolic representation (3 questions). The questions have been empirically validated and of the 10 questions made only 8 were valid, with a degree of reliability of 0.69 (moderate). The degree of difficulty of the questions consisted of 3 questions in the difficult category, 4 questions in the medium category, and one question in the easy category.

After both classes completed the learning process, students in the experimental class and in the control, class were given the same representation test. The data obtained were tested for normality and homogeneity test. After it was obtained that the data were normally distributed and homogeneous, then the data were analyzed using the two-average difference test, namely the t test to prove the hypothesis whether there was a difference in the ability of representation between students learning to use the multimedia-assisted analogy approach and students learning using the conventional approach.

\section{Result and Discussion Results}

The learning process in this study used a multimedia-assisted analogy approach in algebraic material for grade VII students. The learning process is carried out in seven meetings. At first, students were very enthusiastic about paying attention to subject matter with multimedia-assisted real contexts. The teacher explains the concept of algebraic addition using fruits, then the students listen to what the teacher says, students begin to find it difficult when students understand algebraic concepts based on analogy illustrations given by the teacher, then in the end the teacher jointly determines the algebraic concepts that are being studied.

The multimedia-assisted analogy learning steps carried out in the research are presented in Figure 1.

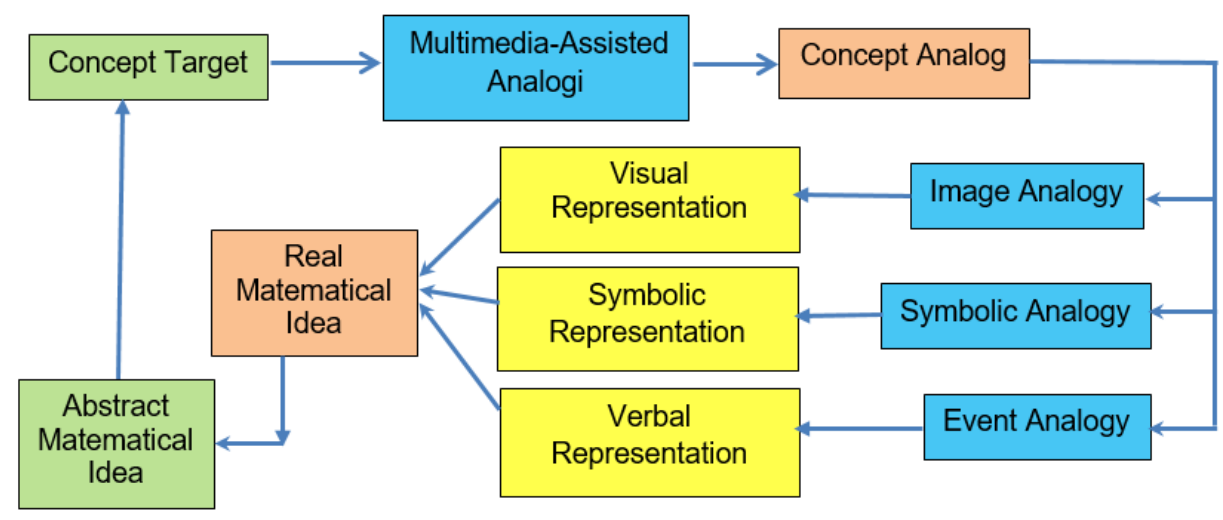

Figure 1. Flow Chart of Multimedia-assisted Analogy Learning

The learning procedure based on diagram 1 is described in detail as follows: Learning mathematics using analogy in the conception consisting of concept target and concept analogy. In this case, a concept target is an algebraic. To explain or introduce the concepts target of algebra to students using the multimedia assisted analogy approach. To explain the concept of the target, the researcher uses concept analog as a learning procedure in order to refer to the concept of algebra. At this stage, Algebra was explained by three kind of analogy, namely image analogy, symbol analogy and event analogy. Image analogy is to assume the variables of ajlabar $x, y$, and $z$ by using the context of fruit names such as apples, pears and 
oranges. Symbol analogy is using various symbols to show a context, for example "if five pineapples are known, state the sentence in a mathematical model". To answer the question, the students filled in 5 pineapples, for example $5 n$ or $5 a$ or $5 x$, where the letters $n$, a or $x$ were notations or symbols that represented pineapples; and analogies, namely events that use the context of events or events to change algebraic form changes. An example is an analysis of the case of a shipment of goods as shown in Figure 2. In that event, students can make a mathematical model of how many apples and oranges are shipped to the modern market and how many apples and oranges are shipped to the modern market. From the analogy of this event, students are expected to be able to form the concept of algebraic operations using distributive properties. In addition, in order for analogy to be real and easy to implement, it is necessary to juxtapose the target concept and analog concept in one view so that it will be easier to compare comparisons.
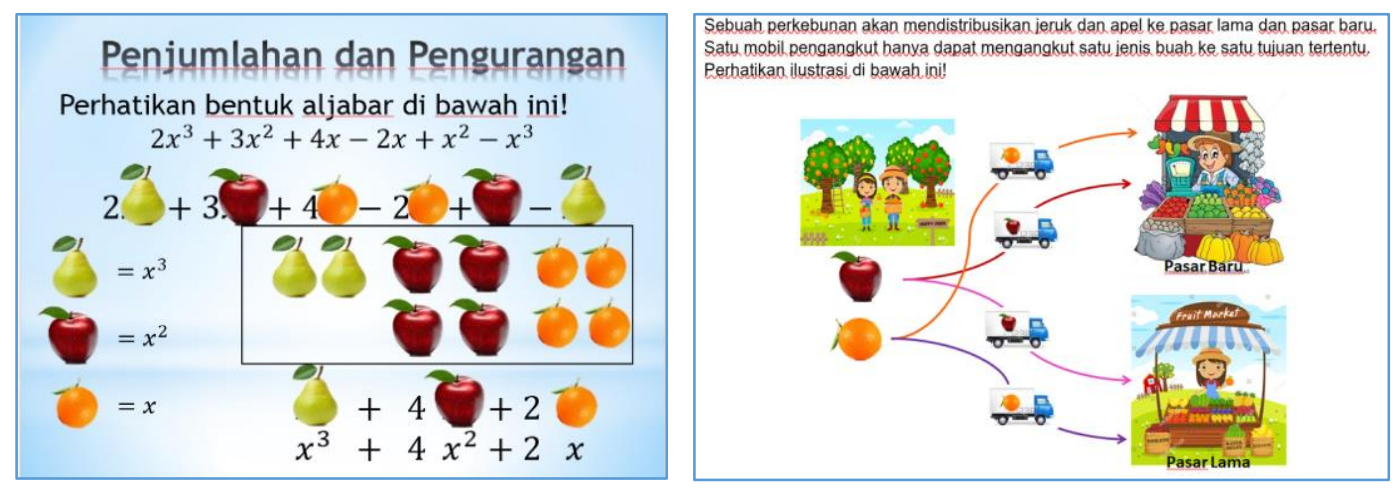

Figure 2. Image Analogy and Event analogy

The teacher explains concept of algebraic form similarity. This similarity is usually expressed by using the sign "=", questions given to students for example, "what is the $x$ value of the following math equation: $5 x+6=3 x-12$ ". To explain this equation, the teacher provides an analogy with the scales (see figure 3 ),

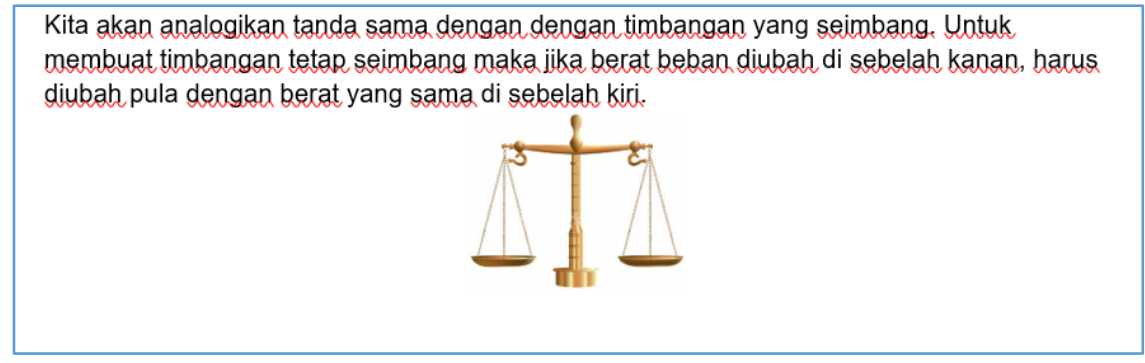

Figure 3. Analogy for Similiarity of Algebra

if the scales are in balance then both bags contain the same object. Then the solution is:

$$
\begin{array}{ll}
5 x+6 & =3 x-12 \\
5 x+6-6 & =3 x-12-6 \\
5 x & =3 x-18 \\
5 x-3 x & =3 x-3 x-18 \\
2 x & =-18 \\
\frac{2 x}{2} & =-\frac{18}{2} \\
x & =-9
\end{array}
$$

both sides are subtracted by 6

both sides are subtracted by $3 x$

both sides are divided by 2

As long as learning process, teacher provides assistance in explaining the concept target to students, remembering that the concept analog will cause misconceptions if students are not properly guided. For example, the concept analog that explains the concept target 
about addition in algebraic patterns, the analog concept will not follow the concept of target multiplication or algebraic division. For example, two different variables, namely water and oil. Water and oil are used as an introduction that two different variables cannot be added together, but cannot be used to explain the concept target of multiplication. Therefore, the use of concept analog must be carefully prepared so that there are no misconceptions in student understanding. The final step is ordering mathematical ideas carried out by students together with the teacher to make concepts from concept analog presented through multimedia to find and understand the concept target.

As explained in the previous section, this study uses two classes as the research sample. The first class as an experiment is a class where students learn using an analogy approach while the second class is a control class where students learn using a conventional approach. After the learning process is complete, both classes are given the same mathematical representations' skills test. The data of Students' mathematical representation based on posttest is presented in Table 1.

Table 1. The Value of Students' Mathematical Representation Ability

\begin{tabular}{ccc}
\hline Statistics & Experiment Group & Control Group \\
\hline Number of samples $(M)$ & 24 & 20 \\
Mean $(\bar{x})$ & 61,25 & 37,85 \\
Median $(M e)$ & 60,835 & 36,5 \\
Modus $(M o)$ & 58 & 23,5 \\
Variance $\left(s^{2}\right)$ & 311,413 & 368,661 \\
Standard deviation $(s)$ & 17,647 & 19,201 \\
Minimum & 17,86 & 10,71 \\
Maximum & 89,29 & 71,43 \\
\hline
\end{tabular}

Based on the data in Table 1, it shows that the students' representation in the experiment group mean value $\overline{x_{e}}=61,25$ and the standard deviation $s_{e}=17,654$; while the students' representation in the control group mean value $\overline{x_{c}}=37,85$ and the standard deviation $s_{c}=19,21$. Its means that the average score of the experiment group is higher in the control group, and the students' representation in the control group is more spread out compared to the experimental group. Visually, the distribution of data in the second group can be seen in Figure 4.

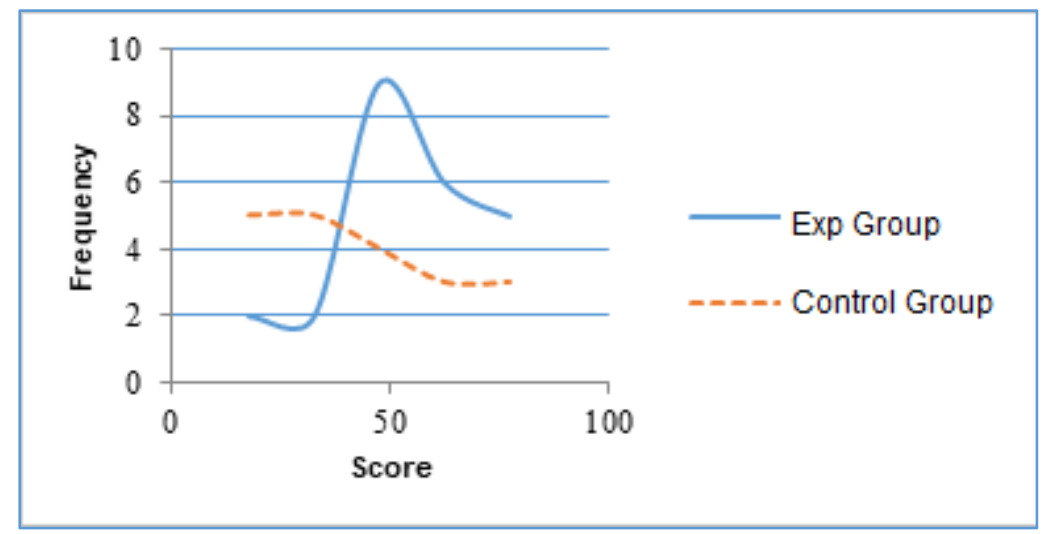

Figure 4. Distribution of students' Mathematical Representation

Figure 4 shows the distribution of students' representations both of groups. It appears that the students' mathematical representation in experiment group is higher than control group, students with lower abilities in experiment group are less than control group, and vice versa, students with moderate and high abilities in the experiment group are higher than those in the control group. 
Furthermore, to determine the difference of students' representation both of groups is significant or not, a different test analysis (t test) is used by taking $\alpha=5 \%$. The results of calculations using the t test obtained $t_{\text {count }}=4.205$ and $t_{\text {table }}=2.018$, because $t_{\text {count }}>t_{\text {table }}$, it was concluded to be $\mathrm{H}_{0}$, in other words that the students' representation whose learning using multimedia- assisted analogy approach was higher than the students' representation of learning conventionally.

Furthermore, the acquisition of the average value of students' mathematical representation of experiment group view from three indicators is presented in Figure 5.

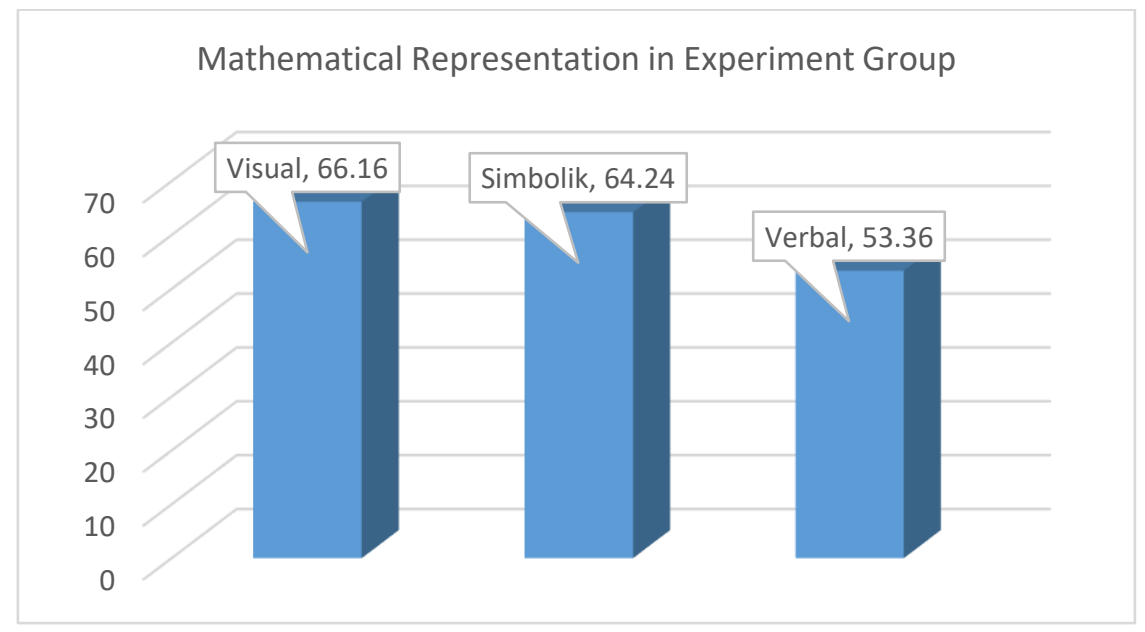

Figure 5. Distribution of students' Representation view from indicators

After knowing the average of students' mathematical representation in experiment group, the researcher then classified the students' abilities in the experiment group based on indicators of representations' skills: visual, symbolic and verbal. This grouping is carried out to determine which indicators increase the highest if learning uses a multimedia-assisted analogy approach. In Figure 5, it can be seen that the representation ability of the visual indicators shows the highest value (66.16), followed by the value on the symbolic indicator (64.24), although the difference of two group is around 2, and the last is the value on the verbal indicator.

\section{Discussion}

Based on the data analysis, it shows that the students' mathematical representation whose learning uses the multimedia-assisted analogy approach is higher than the students' mathematical representation whose learning uses a conventional approach. The learning process with the multimedia-assisted analogy approach provides opportunities for students to think, make hypotheses from concept analog given through illustrations conveyed on power points. From this concept analog, students are able to find the concept target, although it still needs teacher guidance, in other words that concept target is not fully discovered by students but is assisted by the teacher. This is done so that there are no students' misconceptions, this activity supports the developing of students' mathematical reasoning. The learning process using a multimedia-assisted analogy approach greatly helps students in understanding of algebra, terms often used in algebra and algebraic problem solving. All technique is done through image analogies, symbolic analogies, and event analogies. The results of this study are similar with the results of research conducted by Irawati where the learning process with the analogy approach has strong reasoning power in teaching concepts so that students are able to find inspiration, construct knowledge and in the end students are able to understand the concepts of physics (Irawati, 2012). Another study that has succeeded in increasing student understanding using an analogy approach (Guerra, 2018). Students is more understand the concept of photosynthesis if learning is carried out using an analogy approach. Likewise, the research results show that the analogy approach helps high school students 
understand the concept of derivatives (Dwirahayu et al., 2018). Analogy learning with multimedia-assistance will help students visualize real concepts, not only words. The content is in accordance with previous research conducted by Nizham and Thohirudin which states that media or multimedia is a bridge between concepts and the real world, so that the concept illustrations conveyed in the learning process become more real and help students form visualizations in thought, so as to improve mathematic skills (Nizham, 2016; Thohirudin, 2017).

The learning process in the class uses a conventional approach, the material is delivered by teacher in a conventional way, teacher explains the material and students listen what the teacher says. In delivering material, the teacher also provides real examples of the material to be taught. The difference is, in the experiment group the explanation uses multimedia, while in control group, questions are explained by the teacher and accompanied by questions and answers to the students, this activity is also carried out to develop students' mathematical representation. In control group, even though students pay attention to the teacher's explanation, they still have difficulty solving math problems, and students do not try to solve them instead of asking to the teacher, and the teacher guides students to solve the problem, so that students' reasoning is limited to changes in algebraic form. Another alternative is to ask his friend and see the results of his friend's work.

The learning process using the conventional approach does not encourage students make reasoning process. This is similar with the results of Azmi's research that conventional approaches are not able to significantly improve capabilities (Azmi, 2017). Students do not attempt to independently solve high-level math problems, students prefer to ask their teacher or friends if they face some problems, they even prefer to solve problems that are similar to examples. This finding is also similar with the results of research by Minarni which states that in general the learning process which is dominated by teachers does not train reasoning skills and representation skills (Minarni, 2016).

Viewed from indicator of mathematical representation, the indicator "visual" gets the highest score. It is because of images analogous presented at a power point which is able to provide a detailed and clear picture of the concept analog, then students are asked to think about what is in the images presented in relation to the concepts being taught. Through the use of images or various contexts, students are trained to use their reasoning skills, and the mathematical ideas presented in a visual form are better. Whereas in the control group, students' representation does not increase because it is caused by the low of students' reasoning, and the occurrence of misconceptions (Safitri, 2015; Sari, 2018) in presenting mathematical ideas in visual form due to learning dominated by lectures or stories. This is also similar with the opinion of Goldschmidt, that visual analogies have an influence on students' cognitive abilities, and visual analogies are also able to help students represent problems so that mathematical problems will be easily resolved (Goldschmidt, 2001).

The Simbolic representation also shows a fairly good value, it is because in learning using multimedia-assisted analogy approach students are trained to be able to represent the same object with different notations or symbols. As stated by Woleński that formal proof in analogical reasoning also has an important role as analogical reasoning related to human activities (Woleński, 2019). On the other hand, the students' representation ability who learn with conventional approaches is less developed because students are not given the freedom to use different notations, students are only required to solve algebraic problems algorithmically. In the control group, students have a low understanding of algebraic concepts because they do not master the concept, students tend to solve relatively the same questions as the examples given by the teacher, as a result of low understanding it also causes low representation abilities (Minarni, 2016).

For indicator "verbal representation" does not develop well in experiment group. In learning by multimedia-assist analogy, students do more analogy with pictures and analogy symbols must convey oral ideas. The learning process is also assisted by using Student Worksheets. Filling in the Worksheet is dominated by questions that use analogical images and analogical symbols, so that communication does not improve much during the learning process. This is similar with Safitri's opinion that student representation can be low due to factors of low representation ability and conceptual understanding (Safitri, 2015). The ability to 
reasoning and understanding the concept is very influential in the process of the concept analog to concept target, causing procedural flaws, which is a process that bridges the real concept (concept analog) with the abstract concept (concept target).

Increased representation of students whose learning uses a multimedia-assisted analogy approach only occurs in visual representations and symbolic representations, while verbal representations do not a significant increase, this is in line with Guerra's findings that analogy has an important role in enhancing students' knowledge (Guerra, 2011). In a certain thing that analogy needs to consider because analogy has advantages and disadvantages in its use. In line with this, Walliser says that the use of verbal analogy is actually a learning process that focuses on the use of "Mother Language" as a basis in various situations (Walliser, 2017). Furthermore, verbal analogies are used to enrich language through shifting terms from new terms in context of usage. This is what needs to be considered in the use of verbal analogy, where two situations or two objects are associated without making clear the general nature of which they share. So there are times when the use of the analogy approach will improve students' abilities in certain aspects (visual and symbolic), while other aspects do not develop as expected.

\section{Conclusions and Suggestions}

The conclusion of this study is the students' mathematical representation whose taught using multimedia- assisted analogies is higher than the students' mathematical representation whose taught using conventional approaches. However, if it is viewed from the indicators, the analogy approach with multimedia-assistance can significantly develop the ability of visual representation and symbol representation. Meanwhile, the ability of verbal representation is not well developed. So the multimedia-assisted analogy approach is effective in developing the ability of visual and symbolic representations. Based on this, the researcher recommends using the multimedia-assisted analogy approach as an alternative to learning mathematics, especially to develope visual and symbolic representation skills. While the verbal representation needs to be modified the multimedia or use other approaches that are more relevant to train students to convey mathematical ideas verbally.

\section{References}

Annajmi, (2016) Peningkatan Kemampuan Representasi Matematik Siswa SMP melalui Metode Penemuan Terbimbing Berbantuan Software GEOGEBRA di SMP N 25 Pekanbaru. Jurnal Ilmiah Edu Research: 5(2), 67-74. https://ejournal.upp.ac.id/index.php/EDU/article/view/1199.

Azmi, M. P. (2017). Asosiasi Antara Kemampuan Analogi dengan Komunikasi Matematik Siswa SMP. Al-Jabar: Jurnal Pendidikan Matematika, 8(1), 91-100 https://doi.org/10.24042/ajpm.v8i1.902.

Basir, M. A., Ubaidah, N., \& Aminudin, M. (2018). Penalaran Analogi Siswa dalam Menyelesaikan Masalah Trigonometri. WACANA AKADEMIKA: Majalah IImiah Kependidikan, 2(2), 198. https://doi.org/10.30738/wa.v2i2.3213.

Chiu, M. H., \& Wu, H. K. (2009). The roles of multimedia in the teaching and learning of the triplet relationship in chemistry. In Multiple representations in chemical education (pp. 251-283). Springer, Dordrecht. https://doi.org/10.1007/978-1-4020-8872-8_12.

Dwirahayu, G. (2018). Pendekatan Analogi dalam Mengembangkan Kemampuan Matematika Siswa. FITK Press.

Dwirahayu, G., Kustiawati, D., \& Yanti, R.A. (2018). Analisis Kemampuan Berpikir Aljabar Siswa Berdasarkan Miskonsepsi. FKIP Universitas Muhammadiyah Tangerang.

Dwirahayu, G., Mubasyiroh, S. M., \& Mas'ud, A. (2017, October). The effectiveness of Teaching with Analogy on Students' Mathematical Representation of Derivative Concept. In International Conference on Education in Muslim Society (ICEMS 2017) (pp. 57-60). Atlantis Press. https://doi.org/10.2991/icems-17.2018.12. 
Gentner, D., \& Smith, L. (2012). Analogical Reasoning. In Encyclopedia of Human Behavior: Second Edition. (pp. 130-136). https://doi.org/10.1016/B978-0-12-375000-6.00022-7

Glynn, S. (2007). The teaching with analogies model. Science and Children.

Goldschmidt, G. (2001). Visual analogy-a strategy for design reasoning and learning. In Design knowing and learning: Cognition in design education (pp. 199-219). Elsevier Science. https://doi.org/10.1016/b978-008043868-9/50009-7.

Graciella, M., \& Suwangsih, E. (2016). Penerapan pendekatan matematika realistik untuk meningkatkan kemampuan representasi matematis siswa. Metodik Didaktik: Jurnal Pendidikan Ke-SD-An, 10(2). https://doi.org/10.17509/md.v10i2.3180.

Guerra-Ramos, M. T. (2011). Analogies as tools for meaning making in elementary science education: How do they work in classroom settings?. Eurasia Journal of Mathematics, $\begin{array}{llll}\text { Science } \quad \text { and Technology 29-39. } & \text { (1), }\end{array}$ https://doi.org/10.12973/ejmste/75175.

Herdiman, I., Jayanti, K., Pertiwi, K.A. (2018). Kemampuan Representasi Matematis Siswa SMP pada Materi Kekongruenan dan Kesebangunan. Jurnal Elemen, 4(2), 216 - 229. https://doi.org/10.29408/jel.v4i2.539.

Hutagaol, K. (2013). Pembelajaran kontekstual untuk meningkatkan kemampuan representasi matematis siswa sekolah menengah pertama. Infinity Journal, 2(1), 85-99. https://doi.org/10.22460/infinity.v2i1.27.

Innayah, N., Hartoyo, A., \& Bistari, B. Penalaran Analogi Siswa Berdasarkan Tahapan Clement Pada Materi Dimensi Tiga Di Sekolah Menengah Atas. Jurnal Pendidikan dan Pembelajaran Khatulistiwa, 9(9). https://jurnal.untan.ac.id/index.php/jpdpb/article/view/42261.

Irawati, I. (2012). Metode Analogi dan Analogi Penghubung (Bridging Analogy) dalam Pembelajaran Fisika. Jurnal Fisika. https://core.ac.uk/download/pdf/198231099.pdf.

Kartini, K. (2009). Peranan representasi dalam pembelajaran matematika. In Seminar Nasional Matematika Dan Pendidikan Matematika.

Lailiyah, S. (2014). Penalaran Analogi: Tinjauan Tipe dan Komponennya. Seminar Nasional TEQIP Exchange of Experiences 1. https://www.academia.edu/download/53337902/PENALARAN_ANALOGI_TINJAUAN _TIPE_DAN_KOMPONENNYA.pdf.

Loc, N. P., \& Uyen, B. P. (2014). Using Analogy in Teaching Mathematics: An Investigation of Mathematics Education Students in School of Education- Can Tho University. International Journal of Education and Research., 2(7), 91-98. https://www.ijern.com/journal/July-2014/08.pdf.

Minarni, A., Napitupulu, E. E., \& Husein, R. (2016). Mathematical Understanding and Representation Ability of Public Junior High School in North Sumatra. Journal on Mathematics Education, 7(1), 45-58. https://doi.org/10.22342/jme.7.1.2816.43-5.

Nizham, H., Dwirahayu, G., \& Suhyanto, O. (2016). The Influence of Using Visual AID (Operational Box) toward Students' Conceptual Comprehension in Material Number. In Yaya S. Kusuma dkk (Ed.), The Proceedings 5th International Postgraduated." Conference on Research in Education (pp. 135-143). SPS UPI.

Ranisa J., (2016). Kemampuan Representasi dan Komunikasi Matematis Peserta Didik SMA Ditinjau dari Prestasi Belajar dan Gaya Kognitif. PYTHAGORAS: Jurnal Pendidikan Matematika, 11(2), 193-206. https://core.ac.uk/download/pdf/192882236.pdf.

Reys, B., Reys, R., \& Rubenstein, R. (2010). Mathematics Curriculum: Issues, Trends, and Future Directions, 72nd Yearbook. National Council of Teachers of Mathematics. 1906 Association Drive, Reston, VA 20191-1502. 
Richland, L. E., \& Begolli, K. N. (2016). Analogy and Higher Order Thinking: Learning Mathematics as an Example. Policy Insights from the Behavioral and Brain Sciences, 3(2), 160-168. https://doi.org/10.1177/2372732216629795.

Richland, L. E., Holyoak, K. J., \& Stigler, J. W. (2004). The role of analogy in teaching middleschool mathematics. Cognition and Instruction, 22, 37-60. https://doi.org/10.1207/s1532690Xci2201_2.

Sabirin, M. (2014) Representasi dalam Pembelajaran Matematika. Jurnal JPM IAIN Antasari, 1(2), 33-44. https://doi.org/10.18592/jpm.v1i2.49.

Safitri, E., \& Hartoyo, A. (2015). Kemampuan Representasi Matematis Luas Dan Keliling Lingkaran Berdasarkan Teori Bruner Di Smpn 9 Pontianak. Jurnal Pendidikan Dan Pembelajaran, (3), 1-11. http://jurnal.untan.ac.id/index.php/jpdpb/article/view/9734.

Sari, D. P. (2018). Errors of Students Learning with React Strategy in Solving the Problems of Mathematical Representation Ability. Journal on Mathematics Education, 9(1), 121128. $\mathrm{https}: / /$ doi.org/10.22342/jme.9.1.4378.121-128.

Setiadi, Hari, M. (2012). Kemampuan Matematika Siswa SMP Indonesia Menurut Benchmark Internasional TIMSS 2011. Puspendik.

Simms, N. K., Frausel, R. R., \& Richland, L. E. (2017). Working memory predicts children' s analogical reasoning. Journal of Experimental Child Psychology, 166(September 2017). https://doi.org/10.1016/j.jecp.2017.08.005.

Sulastri, M. \& Duskri, M., (2017) Kemampuan representasi matematis siswa SMP melalui pendekatan pendidikan matematika realistik. Beta: Jurnal Tadris Matematika. 10(1), 51-69. http://dx.doi.org/10.20414/betajtm.v10i1.101.

Thohirudin, M., Maryati, T. K., \& Dwirahayu, G. (2017, March). Visualisation ability of senior high school students with using GeoGebra and transparent mica. In Journal of Physics: Conference Series (Vol. 824, No. 1, p. 012043). IOP Publishing. https://doi.org/10.1088/1742-6596/824/1/012043.

Walliser, B., Zwirn, D., \& Zwirn, H. (2017). Reasoning by Analogy. https://www.researchgate.net/publication/320004730.

Woleński, J. (2019). Logical Problems in Analysis of Analogy. Philosophies, 4(2), 29. https://doi.org/10.3390/philosophies4020029.

Zuchri, S. (2017). Manipulatif Berbantuan Geogebra untuk Membantu Pemahaman Siswa dalam Menyelesaikan Word Problem Kelas 7 SMP. Euclid, 4(2). https://doi.org/10.33603/e.v4i2.420. 